\title{
Henry Wallace's Visit to China: an Ultimate Effort to Send the U.S. Army Observer Group to Yan'an
}

\author{
Hu Yueying
}

\begin{abstract}
In the later period of WW II, American Vice President Henry Wallace became the highest ranked visitor to China during the war, and even in the modern history of Sino-US relations, with a purpose that has been argued over till this day. Based on a thorough study of the event, the cause and effect of Wallace's visit, as well as other related events that happened in the same period, especially in consideration of the Operation Matterhorn that "was given top priority in both men and materials, second only to the secret Manhattan Project", Wallace's visit can be seen as an ultimate effort to send the U.S. Army Observer Group to Yan'an and provide crucial technical support to the Operation Matterhorn. This is a necessary and sufficient condition for Vice President Henry Wallace to visit China.
\end{abstract}

Index Terms-Wallace's visit to China, U.S. army observer group in Yan'an, operation matterhorn.

\section{NeGOtiation BETWEen SinO-US}

"In June 1944, a month of historical significance, the major event that happened in China was President Roosevelt sending an important visitor to China. [1]" Vice President Henry Wallace's visit to China was then incurring (and even keeps on incurring decades afterwards) various suspicions and concerns about the entire event in all walks of life. Was it like what some people back in the U.S. guessed that President Roosevelt had intended the leave of Wallace for the election strategy? Or as Generalissimo Jiang Kai-shek had wished, to play meditation in the Sino-USSR conflicts? Or as Yan'an had expected, to go between China's Nationalist Party and Communist Party?

Regardless of all the suspicions, concerns and worries, Wallace's visit actually reached a concrete and absolute goal, "that is, exerting some pressure upon Chiang Kai-shek on behalf of President to mobilize the U.S. Army Observer Group to Yan'an." The mission of the U.S. Army Observer Group was to serve the Operation Matterhorn ${ }^{1}$ in Chengdu that "was given top priority in both men and materials, second only to the secret Manhattan Project [2]", namely, to provide information including weather reports, to facilitate the operation of the $20^{\text {th }}$ Air Force of U.S Army, to dispose of the wreckage of B-29s, then state-of-the-art heavy bombers,

Manuscript received October 1, 2017; revised November 23, 2017.

$\mathrm{Hu}$ Yueying is with Sichuan University, China (e-mail: 498930178@qq.com).

The Operation Matterhorn that flied B-29s from India and Chengdu bases to bomb the Japanese home islands was not welcome among the frontline officers and history researchers, because of its unnoticeable results. Only the top decision makers like President Roosevelt and Henry Arnold, Commander of the U.S. Army Air Force showed passion about it, and the passion might be linked with the Manhattan Project. and to rescue the downed pilots in northern China. ${ }^{2}$

Wallace's visit was not America's first effort to send an observer group to the Communist-occupied area in China. Not long ago, on Feb 10, 1944, President Roosevelt took the first initiative to discuss with Generalissimo Chiang about the issue:

As our common war against Japan increases in intensity and as we steadily move toward the citadel of Japan, it becomes apparent that, in addition to defeating Japan on the seas and in the air, we must engage and destroy the main body of the Japanese army before we can surely attain the final victory. The principle concentration of the Japanese army is in north China and Manchuria. We now begin with preparations to crush that formidable Japanese force.

Information at present regarding the enemy in north China and Manchuria is exceedingly meagre. To increase the flow of such information and to survey the possibilities of future operations, both ground and air, it appears to be of very great advisability that an American observers' mission be immediately dispatched to north Shensi and Shanxi Provinces and such other parts of north China as may be necessary.

May I have your support and cooperation in this enterprise? ${ }^{3}$

In this telegraph, Roosevelt expressed a major purpose of requesting Chiang's permission to dispatch "an American observers' mission" and increase the flow of military information. In the war time, for the "common war against Japan", it was not a rare thing for America to send all kinds of groups to China. But this time was different because the "observers' mission" would go to Shanxi (Shensi), Shaanxi (Shanxi) and other similar parts of north China, which were the sensitive places Chiang kept guard against.

Besides, Roosevelt was ambiguous about the motive and objective of the mission, just saying that "the principle concentration of the Japanese army is in north China and Manchuria" and "we must engage and destroy the main body of the Japanese army before we can surely attain the final

\footnotetext{
${ }^{2}$ The intense attention to the rescue operation by the U.S. Army Observer Group should be caused by the specialty of locations. The operation covered all the areas that the $20^{\text {th }}$ Air Force could reach. It was not the first initiative of the kind for the U.S. Army to build weather stations in northwest China See A Different Kind of War by Milton Miles, translated and published by Xin Sheng Bao Editing Department (Taiwan), 1969.

3 The Chinese version of this telegraph can be found in Compiled Important Materials of the Republic of China: Anti-Japanese War, Vol. 3, War-time Diplomacy (I), compiled by Qin Xiaoyi, Party History Committee under the Central Committee of Nationalist Party of China. The Chinese version is also included in Communications Between Generalissimo Chiang and President Roosevelt, compiled and translated by Guo Rongzhao, published by China Research Center, 1978, p210. The English origin can be found in Foreign Relations of the United States, 1944, Vol. VI, China, 1967, Published by Government Printing Office, Washington, D. C.
} 
victory". However, according to the China-based strategy settled in 1943, America wouldn't launch any large-scale ground attack or the final battle against Japan on the territory of China. ${ }^{4}$ Since Chiang was already in deep worries about the Communists growing more powerful after contacts with America, the ambiguity in Roosevelt's telegraph increased Chiang's confidence in America's intention of going between the two parties. From his telegraph replied on Feb 22, we can find how Chiang reacted to the request:

I shall be glad to do all I can to facilitate your plan to send an American Observer Mission to gain more accurate information regarding the troop concentration of our common enemy in North China and Manchuria. I have already issued instructions to the Ministry of War to get in touch with Gen Stilwell's Headquarters in order to map out a prospective itinerary for the mission in all areas where the political authority of the National Government extends and wherever our Army is stationed [3].

Telegraph exchanges between national top leaders should be very careful with the wording. The reply by Chiang, though as short as less than a hundred words, gave full display of the sender's considerations. First, Chiang adjusted the manner to speak of the mission so that it could appear superior to the Communists and the ruling position of the Nationalists be reconfirmed.

Second, by saying that he would do all he could, Chiang implied that difficulties, obstructions might be encountered in sending this mission to the Communist-occupied area and he as the leader of the only legal government in China might be of no help. And this attitude, from the perspective of America, could be a complaint or confession about how weak Chongqing was in handling the problem of Communists, or a powerless threat out of dislike.

Then Chiang played his well-developed political talent to pass down the sensitive problem, by issuing "instructions to the Ministry of War to get in touch with Gen Stilwell's Headquarters in order to map out a prospective itinerary for the mission". In so doing, he could lower the grade of the mission and lessen the importance of the Communists on one hand, and on the other, direct the dispatch plan into a detour path of preparation where buffers and obstructions might occur and even end the path.

The last part of the telegraph should be deemed the bottom line of Chiang. If the mission was bound to operate, it would be only permitted "in all areas where the political authority of the National Government extends and wherever our Army is stationed." In other words, "the Generalissimo agrees to send the mission to the areas controlled by the political and military forces of the Central Government, not the Communist-occupied areas. [4]"

Chiang's telegraph sent a clear signal that he would not see

\footnotetext{
${ }^{4}$ According to the decisions of the Joint Staff Planners (JSP) on May 5 , 1943, the 1943-44 overall strategies of the U.S. in Pacific and Far East Areas included: first, keep the all-round military pressure on Japan; second, maintain China's war against Japan. (See Joint Staff Planners, Global Estimate of the Situation, 1943-44, May 5, 1943, Franklin D. Roosevelt Library Digital Archives, Safe Files, Box 2, Current Strategic Studies Book 1 Index.) Whatever positive cooperation the frontline officers of the U.S. Army and Navy made with Chongqing or Yan'an, America wouldn't launch a final battle against Japan from the territory of China.
}

the Communists' contacts with America, direct or indirect via the government. And his reply caused Roosevelt to worry about the possibility of reaching an agreement. Roosevelt had to ask Chiang one more time for permission to the dispatch plan in a telegraph dated Mar 22, 1944:

It will be helpful in the efforts of all of us to get more accurate information from that area when my military observers authorized in your message of 22 February arrive on the scene.

General Stilwell has been instructed to complete arrangements with the Minister of War for the mission's itinerary as soon as practicable [5].

Roosevelt restated the need of the mission's arriving "on the scene", that is, going to the Communist-occupied area. No matter Chiang would like it or not, he had instructed people to complete arrangements.

In a period afterwards, Chiang seemed to be avoiding this issue and stopped talking about it. Roosevelt also gave up discussing it in telegraphs. But the plan of sending a military observer group to the Communist-occupied north China was not dropped at all. The later facts would show that Roosevelt was thinking of a more effective way to achieve the goal, that is, Wallace's visit to China.

\section{A Visit Without CleAr TARgET}

Upon the release of the news that President Roosevelt would send Vice President Wallace to visit China, speculations arose on all parties. According to America's official disclosure, Wallace's visit was "intended to meet with China's leaders, observe China's agricultural conditions and inspect how the U.S. Army does in China." But some people in the U.S. commented that "Wallace has the chance to be re-elected in this election year and he just finds an excuse to leave America while the Democratic National Convention is held. [6]" The Chinese heard about the news in the next month of release, April 1944 and some of the Nationalists considered Wallace's visit an effort to "meditate the Sino-USSR conflicts and go between the Communists and Nationalists" [7]. And this sort of consideration caused Chiang Kai-shek to immediately instruct American ambassador to respond that "Vice President Wallace comes to China, if in hope of activating the cooperation between the Nationalists and Communists, then China's anti-Japan war will be sabotaged and the Communists will grow more powerful and their hazards more difficult to remove. [8]"

Whatever the guessing was, Wallace's delegation departed in May. On the delegation there were Owen Lattimore, the political consultant of Chiang Kai-shek in 1941-42 and the then director of Pacific Bureau, Office of War Information (OWI) of the U.S. Army; John Carter Vincent, representative of State Department appointed by Cordell Hull, Secretary of State (Vincent's major role was to prevent Wallace from making unfulfillable promises to Chiang, and he was regarded by the Nationalists "a sympathizer of the Communists [9]"); and Hazard.

Starting from Alaska, Wallace's delegation travelled first to the USSR airport in northeastern Siberia, near the Bering Strait, then reached places like Yakutsk and Magadan, rested 
a little, and continued from Komsomolsk by the side of Heilongjiang, via Irkutsk, Ulan-Ude, Minussinsk, Semipalatinsk, Tashkent, Alma-Ata to China's Urumqi and Chengdu, and finally arrived in Chongqing on June $20 .^{5}$

On Jun 21, 1944, Wallace held the first meeting with Chiang in Chongqing, exchanging diplomatic talks and, under Chiang's guidance, discussing Sino-USSR conflicts on borders in Xinjiang. This indeed gave an expression that America was seeking to step into Sino-USSR relations. No wonder people in this day still think "Roosevelt had decided to send Vice President Wallace to China" for the purpose of "meditating conflicts between Nationalists and Communists, between China and USSR [10]", or "Wallace was sent to pacify and encourage Chiang, and preach the mutual trust among allies." ${ }^{6}$ There's surely a reason underlying such a belief. "Judging from the news reports", people would be easily convinced that Wallace went to China "to prepare a necessary condition for piecing up the separated country. [11]"

In the meeting, Wallace also reported "the talks with General Marshall and Henry Stimson, Secretary of War, about China's situations upon departure", and conveyed Roosevelt's diplomatic concerns over China's domestic affairs (Nationalist-Communist relations). These diplomatic concerns, however, "caused confusion" again and made "Chiang further believe that the U.S. President was willing to go between Nationalists and Communists. [12]" And the worries expressed by Chiang also shed light on how he thought of Wallace's coming to Chongqing. In his mind, Wallace came to Chongqing for two "tasks": The first was to mediate Sino-USSR relations and the second was to discuss "Nationalist-Communist cooperation". For the two tasks, Chiang himself harbored opposite expectations. The first was quite hoped-for as he had mentioned a lot about the disputes over Sino-USSR borders in his exchanges of telegraphs with Roosevelt in March and April. He was looking forward to America's intervention in the disputes. The second, however, was something he feared most. Whatever Chiang's expectations were, neither of the two was the purpose of Wallace's delegation assigned by Roosevelt.

As a matter of fact, Roosevelt was not so passionate about Wallace's travel to USSR and he even "warned him not to go to Moscow [13]" before his departure, trying to avoid becoming an arbitrator between China and USSR. After their arrival in Chongqing, Vincent also reminded Wallace of "not making Generalissimo believe the U.S. would play more than a role of mediator in Sino-USSR relations", because at that time "trying to be an arbitrator between Stalin and Chiang is a duty hard to perform [14]".

\footnotetext{
${ }^{5}$ This route of Wallace's delegation (see Memoirs of Owen Lattimore, Chiang Kai-shek's American Consultant, published by Fudan University Press, 1996, pp.166-170) is similar to Routes B and C of the three routes Henry Arnold suggested in May 1942 to travel into China: Alaska-

Markova-Mimekon-Yakutsk-Bodaibo-Irkutsk-Urga (present Ulan Bator) - Lanzhou - Chongqing (see H. H. Arnold, to FDR, Subject India-Burma-China Ferry Route, May 7, 1942, Franklin D. Roosevelt Library Digital Archives, Safe Files, Box 2, China Index). This might be the strategic meaning Arnold had imagined of establishing such a route.

${ }^{6}$ See The China Tangle: The American Effort in China from Pearl Harbor to the Marshall Mission, Herbert Feis, translated and published by Beijing University Press, 1989, p.165. It is noticeable that in this book, Herbert Feis has expressed contradictory views about Wallace's visit to China.
}

There's a good reason to explain why people are inclined to regard Wallace's visit as an effort to mediate Sino-USSR relations. In a telegraph wired on March 17, Chiang told Roosevelt in details that, on March 11, "the Chinese troops stationed in Xinjiang Province were cracking down on bandits in Houban, 70 kilometers off the Outer Mongolia boundary, between Chenghua and Qitai, when they were attacked by two rounds of air bombing and machine-gun shooting from the direction of Outer Mongolia; there were two airplanes in the first round and ten in the second, all painted with the Soviet Union's red-star emblem. The same kind of airplanes came twice on the $12^{\text {th }}$ day and dropped bombs too." Chiang thought that "this event should not be seen as something local, but an extremely important sign of Soviet Union's current and future strategy in the Fast East. [15]" And Roosevelt's response to this quite detailed telegraph, as shown in the previous telegraph sent on the $22^{\text {nd }}$ day, was to play down the importance of the event as Chiang did to something of the other party's care, by merely saying sorry [16] and shifting the topic to the Observer Group.

Later, in the telegraph wired on April 3, Chiang again put aside Roosevelt's urgent inquiry about the Observer Group and gave more details on the event occurring off the Sino-USSR boundary that Roosevelt did not follow much. The discussion was concluded by Roosevelt's suggestion "to temporarily lay the event aside [17]" on April 10.

From the above-mentioned diplomatic texts, we may find that Chiang and Roosevelt were harboring different intentions and trying to avoid the issue of the other party's concern. Especially for Chiang, he definitely knew what Roosevelt had meant, but he turned away to overlook the quite alarming and worrisome question.

\section{A True GoAls: Collect InTELLIGENCE FOR B-29}

After Wallace arrived in Chongqing, Brigadier Benjamin Ferris from the China-Burma-India (CBI) Theatre wired him a telegram, probably as a reminder that the essential task of the delegation was to obtain Chiang's permission to send the U.S. Army Observer Group to the Communist-occupied area including Yan'an". "The Communists are controlling most of the rural area in north China and their bases extend from northern Shaanxi to the coast, all along the Yangtze River." Although the U.S. "has a lot of reasons, military or political reasons that are obvious, to hope for contacts with the Communists, the military reasons are more urgent in the current war conditions, and more persuasive (to the Chinese) [18]".

In the telegraph, Ferris analyzed the connection between sending the Observer Group to Yan'an and the $20^{\text {th }}$ Bomb Command of the $20^{\text {th }}$ Air Force of the U.S Army: Since the Japanese forces on the Asian mainland "coexisted" with the Communists in north and northeast China, the Communists could be resorted to for collecting the Japanese information in this area. George E. Stratemeyer (Commanding General of

\footnotetext{
${ }^{7}$ It's quite understandable for Wallace to fail in grasping the essence of his visit. Like President Truman who didn't know about the atomic bomb plan before assuming the office, Wallace, even as Vice President, could probably mistake the purpose of sending a U.S. Army Observer Group to Yan'an, and tend to care more about the mediation job between China and Soviet Union, between the Nationalists and Communists, which would be of "great political significance". So there arose a need for the frontline officers of the U.S. Army to "remind" Wallace of the real purpose.
} 
the Army Air Forces' India-Burma Sector) and Kenneth B. Wolfe (Commander of $20^{\text {th }}$ Bomb Command) once analyzed the first bombing of the Japanese home islands ${ }^{8}$ and came to the conclusion that it was absolutely necessary to contact north China. The contacts could benefit in collecting information of the bombing targets and evaluating the bombing effects, rescuing pilots, and even knowing the situations of allies. Ferris explicitly stressed that "it is very urgent to dispatch observers to the Communist-occupied area and the need will grow more urgent with the development of the anti-Japan war." This was because "the $20^{\text {th }}$ Bomb Command is about to launch a new round of attacks over the Japanese home islands, and the frontline is sure to extend into the Communist-occupied area." Ferris urged Wallace to "take new measures, stick to the suggestions put forth in the April's document, as well as the needs of the $20^{\text {th }}$ Bomb Command, make sure to get Generalissimo's permission [19]".

To rectify the wrong impression that Chiang had drawn from the $21^{\text {st }}$ day meeting, Wallace and Vincent decided to shift the topic of the $22^{\text {nd }}$ day meeting from Sino-USSR relations and Nationalist-Communist relations to "general military situations in Eastern Asia and all measures needed to take", that is, "to accelerate the end of war and reduce the loss of American lives", "to send America's military information group to northern China so that they could get information and rescue the lives of American pilots [20]".

For fear that the other party might fail to understand, Vincent specially figured out that the military force in need of information was the B-29 bomber unit stationed in Chengdu. This unit was surely the $20^{\text {th }}$ Squadron of the $58^{\text {th }}$ Wing, the $20^{\text {th }}$ Air Force of the U.S Army, which had been assigned to carry out the Operation Matterhorn. To persuade Chiang and dispel his greatest misgivings, Vincent not only explained the specific objectives of the Observer Group, but also made it clear that "the U.S. Army has no interest in the Communists, but has urgent needs to launch an attack against Japan from the land of China". He suggested that the Generalissimo should "separately handle the goal of collecting information that the U.S. Army assigns to a task force and the problem of his achieving an agreement with the Communists, because these two are actually different issues." In addition, he specially mentioned the B-29 bomber unit stationed in Chengdu was in need of information and "this is a real problem that the U.S. Army faces." ${ }^{9}$

The clear explanation given by the American party, to a certain extent, relieved Chiang's worries about the Communists' growth in power after contacts with the U.S. Army. The top-ranked interactions between the two countries

\footnotetext{
8 "The first bombing of Japanese home islands" should be the Doolittle Raid of B-25s launched from the USS Hornet in 1942. Although this raid was a success to the Pacific Operations of the U.S., it caused an immense loss to the Chinese.

${ }^{9}$ See The Historical Records of Republic of China (First Draft), from April to June, the $33^{\text {rd }}$ year of Republic of China, compiled by Qu Shaohua, published by (Taiwan) Central Cultural Relics Supplier Press, 1993, p.793. There's one point of view that thinks the Wallace-Chiang meeting "involved Sino-US relations, Sino-USSR relations, Nationalist-Communist relations and China's domestic situations in the fields like economy and military, and especially emphasized Nationalist-Communist relations." (Yu Guo: "Comments on Wallace's Visit in China in 1944", Journal of Yangzhou College of Education, Issue No.6 of 2006, p.36) Comparing this point of view with the conversations conducted between Wallace and Chiang, one could have the feeling that the historical facts and confusions are just mixed, not to be told clearly.
}

in the past four months made Chiang have no other choice but to believe that the information group that the U.S. wanted to dispatch so "urgently" ${ }^{10}$ was really for the Operation Matterhorn $^{11}$. Therefore, Chiang gave up the delay strategy and explicitly nodded at the dispatch plan, saying that the Observer Group could be dispatched without the need of reaching an agreement with the Communists and under the instructions of the Military Committee of China, rather than the U.S. Army.

In the meeting held on the morning of the $23^{\text {rd }}$ day, Wallace received a telegraph from Roosevelt that urged him to ask for permission to send a military observation group to the Communist-occupied area. He read the telegraph out to Chiang, who replied with a positive answer to the request. Brigadier Ferris, who had given Wallace a push in the dispatch issue, participated the afternoon meeting in person. He discussed many details with Chiang: the observation group would keep in direct contact with the U.S. Army's headquarters; the date when the group got dispatched; the group would be comprised of 16 to 20 members, with different assignments for each member... Chiang also raised an objection to the name of the group that initially used the word "mission". It should be replaced with "observer group", as suggested by Madame Chiang Kai-shek [21].

As to the abrupt change of Chiang's attitude toward the dispatch issue, John Paton Davies (an old China hand born in Sichuan, as well as an officer appointed by the State Department to Stilwell's headquarters) described as follows: "We're not sure whether it is because the argument is convincing or out of other considerations, the Generalissimo abruptly agrees upon the dispatch of a military observation group. [22]" There's also a point of view that "no convincing reason has been given for Chiang's abrupt change and one possibility cannot be excluded that Wallace agreed to advise Roosevelt to trade for the nod with promotion of Chennault to Stilwell's position [23]".

The wording "abruptly agrees" and the point of view about the trade for the nod with promotion of Chennault might have ignored the frequent direct exchanges between Chiang and Roosevelt since February of the same year. In fact, Chiang had nodded at the dispatch plan at the very beginning, but he signaled the greenlight step by step, and with specific conditions. The sense of "abruptly agrees" might also have missed such an important detail that, during his meeting with Chiang, Wallace not only received a warning from Brigadier Ferris, but also a telegraph from Roosevelt giving further

\footnotetext{
${ }^{10}$ Chiang once said, the greatest help that the U.S. might offer to the Nationalist-Communist reconciliation was to behold the Communists in a detached way and the U.S. should not dispatch the Observer Group so urgently. (See Dragon by the Tail, by John Paton Davies Jr., translated and published by the Commercial Press, 1996, p.273) This statement reflected Chiang's worries (no matter for what reasons the Observer Group would be dispatched to Yan, the Communists were bound to grow arrogant) on one hand, and the really urgent need of the U.S. to send the Observer Group on the other.

${ }^{11}$ Since the U.S. Navy Observer Group set up by Miles could directly build weather stations on the desert, why wouldn't the U.S Army Observer Group just follow suit? Perhaps the U.S. Army Observer Group was sent to Yan'an for the sake of two things: one was to serve the Operation Matterhorn, and the other to do the "political job" of meditating the Nationalist-Communist relations. (This speculation has been instructed by Prof. Chen Tingxiang.)
} 
instructions on the dispatch issue. ${ }^{12}$ It was this "ultimatum-like [24]" telegraph that had pushed Chiang to say a definite yes to the dispatch plan.

After a series of efforts, Washington was finally able to send the U.S. Army Observer Group to Yan'an. And this action, in the eyes of the Nationalists and even the Communists, was more or less a gesture to show recognition or friendliness toward the Communists. But this gesture was somehow a subjective speculation of both parties, judging from the episode of Wallace's visit. There existed such a trend of pan-politicization, not only in war-time China, but also in America, where the post-war McCarthyism accused all those American citizens who had links with the Chinese Communists of "losing China". Wallace naturally became a victim of the anti-Communist wave. He was charged with executing the Communist roadmap, because "two members of his delegation to China, Lattimore and Vincent, were Communists hidden in America." 13

The theory that Wallace accepted the influence of pro-Communist figures while visiting China can be proved wrong by the "recommendation letter" Wallace wrote to Roosevelt after the visit. In the letter written on June 28, 1944 in New Deli, Wallace advised Roosevelt to substitute Stilwell for Wedemeyer. He said:

Chiang informed me that Stilwell does not enjoy his confidence because of his alleged inability to grasp over all political considerations. I do not think any officer in China is qualified to undertake the assignment. Chennault enjoys the Generalissimo's full confidence, but he should not be removed from his present military position...

While I do not feel competent to propose an officer for the job, the name of General Wedemeyer has been recommended to me and I am told that during his visit here he made himself persona grata to Chiang [25].

If we reason with the logic of opposing whatever the enemy supports and supporting whatever the enemy opposes, Wallace's advice to substitute Stilwell, who was "a veteran pro-Communist figure", for Wedemeyer, who "made himself persona grata to Chiang" was indeed "a definite anti-Communist action [26]" that would destroy his chance to go to Yan'an in person. And his recognition of Chennault was also powerful support for Chongqing. However, Wallace's effort to get the dispatch permission was alleged a pro-Communist action that "built contacts with the Chinese Communists under the name of collecting military

\footnotetext{
${ }^{12}$ David D. Barrett (who experienced the history in person, in his work Dixie Mission: The United States Army Observer Group in Yenan, 1944, translated and published by Liberation Army Press, 1984, p.29), Pete Viadmilov (The Viadmilov Diaries Yanan China: 1942-1945, translated and published by Modern Historical Materials Compilation Press, 1980, p.236 ), and E. J. Kahn, Jr. (history researcher, in his work The China Hands: America's Foreign Service Officers and What Befell Them, translated and published by Xinhua Press, 1980, p.136) all mentioned this telegraph from Roosevelt to "reinstate the need to dispatch an observer group to Yan'an". It is unknown, however, whether this telegraph was sent to Wallace or Chiang, or passed on to Chiang by Wallace. And no text of this telegraph is given in these related documents. The author also failed to find the text of this telegraph in Franklin D. Roosevelt Library.

${ }^{13}$ Letter to the Vice President Transmitting Correspondence from Henry A. Wallace Relating to His Trip to the Far East in 1944, September 23, 1951, Public Paper of the President Harry S. Truman, 1945-1953, Harry S. Truman Library and Museum.
}

information". The contradiction implied in the allegation at least proves that, although the Nationalist-Communist relationship was a mere opposition, the attitudes of the American society toward the two parties were complicated, not an either-or dual model.

\section{CONCLUSION}

How valuable was the meteorological information collected by the U.S. Army Observer Group in Yan'an? Curtis E. LeMay, commander of the $58^{\text {th }}$ Bomb Wing of the $20^{\text {th }}$ Air Force, had confessed when talking about the B-29 operation conditions in execution of the Operation Matterhorn: "Weather information on Japan is lacking, as the Russian refuse to provide"; the weather information had to be provided by "liaison officers in the Communist-occupied area, the U.S. Navy dispatches to the Gobi Desert, and the observation balloons flied to Japan [27]", for operation instructions and pilot rescue.

To sum up, the U.S. Army Observer Group in Yan'an offered crucial technical support to the Operation Matterhorn. It greatly facilitated the bombing operations against the Japanese home islands. Even after the evacuation of the group, the Communist meteorological stations that the group had helped establish played a key role in the U.S. anti-Japan bombing operations ${ }^{14}$. One typical example of the supportive role was the drop of atomic bombs in 1945. As the U.S. discloses, on Aug 5, 1945, the day before the drop of atomic bombs over Hiroshima, "at the command of Mao Zedong, the radio stations in northern China aired the key 24-hour weather forecast of Japan. [28]" Weather on the Japanese home islands is under the influence of both Pacific Ocean and Asian continental air masses, so the weather forecast always requires the meteorological data collected in northwestern China. That's why the weather information provided by the Chinese Communists appeared so necessary and valuable.

Therefore, the urgent need to effect the dispatch of the U.S. Army Observer Group to Yan'an and facilitate the execution of the Operation Matterhorn was a necessary and sufficient condition for Henry Wallace's visit to China.

\section{REFERENCES}

[1] E. J. Kahn, Jr., The China Hands: America's Foreign Service Officers and What Befell Them, Qunzhong Publishing House, p. 94, 1990.

[2] J. Baugher, Boeing B-29 Superfortress, ch. 9, Operation Matterhorn. [Online]. Available: http//www.csd.uwo.ca/Elevon/baugher_us/b029-s html

[3] The telegraph sent by generalissimo Chiang from Chongqing to president Roosevelt that promises all efforts to help dispatch a military observation group in China for collecting enemy's information (Feb. 22, 1944), [A], Compiled Important Materials of the Republic of China: Anti-Japanese War, vol. 3, War-time Diplomacy (I), [Z], compiled by Qin Xiaoyi, Party History Committee under the Central Committee of Nationalist Party of China, pp. 164-5, 1981.

[4] Memorandum of general Ferris asking vice president Wallace to request generalissimo Chiang for permission to the dispatch of the U.S. army observer group to Yan'an (June 1944), Foreign Relations of the United States, vol. vi, pp. 102-5, 1967.

[5] The telegraph sent by the U.S. president Roosevelt to generalissimo Chiang to inform that general Stilwell has been instructed to work with

\footnotetext{
${ }^{14}$ While doing the regular jobs such as weather observation, the U.S. Army Observer Group also accepted the invitation of the Communists to train a batch of weather technical staff for the Communists. See "Yan'an, the Cradle of China's Meteorological Undertakings", by Wu Juan, Sacred Land Quarterly, 2000, Issue No.3.
} 
China's minister of war for dispatching an observer group to collect information on China's borders (Mar 22, 1944) [Z], Compiled Important Materials of the Republic of China: Anti-Japanese War, vol. 3, War-time Diplomacy (I), [Z], p. 165.

[6] The telegraph sent by Liu Kai, counselor of the ministry of foreign affairs, from Washington to report that the main purpose of the U.S. vice president Wallace's visiting china is to inspect china's agriculture and the U.S army stationed in China (Apr 12, 1944) [Z], Compiled Important Materials of the Republic of China: Anti-Japanese War, vol. 3, War-time Diplomacy (I), [Z], p. 859.

[7] The telegraph sent by Wei Daoming, the Chinese ambassador to the U.S., from Washington to generalissimo Chiang to report that the U.S. vice president Wallace's visiting china seems an intention to discuss Sino-Ussr relations and problem of the Chinese communists (May 15, 1944) [Z], Compiled Important Materials of the Republic of China: Anti-Japanese War, vol. 3, war-time diplomacy (i), [z], p. 861.

[8] the telegraph sent by generalissimo Chiang to Wei Daoming, the Chinese ambassador to the U.S., from Chongqing to request for an unofficial notice to vice president Wallace that if his visiting china is an intention to meditate nationalist-communist relations, china's anti-japan war will be sabotaged (may 20, 1944) [z], compiled Important Materials of the Republic of China: Anti-Japanese War, vol. 3, War-time Diplomacy (I), [Z], p. 862.

[9] Huang Renlin, "Forty Years' Secret Service Director for Chiang Kai-shek", [A], Huang Renlin's Memoirs, [M], Tuanjie Publishing House, p. 81, 2006

[10] H. M. Yu, "Preparation and decision-making of the U.S. dispatching a military observation group to Yan'an," History Research of the Communist Party of China, vol. 3, p. 45, 2006.

[11] Pete Viadmilov, The Viadmilov Diaries Yanan China: 1942-1945, Modern Historical Materials Compilation Press, p. 237, 1980.

[12] E. J. Kahn, Jr., The China Hands: America's Foreign Service Officers and What Befell Them, Xinhua Press, p. 136, 1980.

[13] J. Paton Davies Jr., Dragon by the Tail, the Commercial Press, p. 270, 1996.

[14] Jo. Paton Davies Jr., Dragon by the Tail, the Commercial Press, p. 272, 1996.

[15] The telegraph sent by generalissimo Chiang from Chongqing to the U.S. president Roosevelt to inform the recent big events closely related to the Far East war (Mar 17, 1944), [Z], Compiled Important Materials of the Republic of China: Anti-Japanese War, vol. 3, War-time Diplomacy (I), [Z], p. 164.

[16] The telegraph sent by the U.S. president Roosevelt to generalissimo Chiang to inform that general Stilwell has been instructed to work with china's minister of war for dispatching an observer group to collect information on china's borders (Mar 22, 1944) [Z], Compiled
Important Materials of the Republic of China: Anti-Japanese War, vol. 3, War-time Diplomacy (I), [Z], p. 165.

[17] The telegraph sent by the U.S. president Roosevelt to inform the recent big events closely related to the Far East war (Apr 10, 1944), [Z], Compiled Important Materials of the Republic of China: Anti-Japanese War, vol. 3, War-time Diplomacy (I), [Z], p. 164

[18] Memorandum of general Ferris asking vice president Wallace to request generalissimo Chiang for permission to the dispatch of the U.S army observer group to Yan'an, Foreign Relations of the United States, vol. vi, pp. 102-5, 1967.

[19] Memorandum of general Ferris asking vice president Wallace to request generalissimo Chiang for permission to the dispatch of the U.S army observer group to Yan'an, Foreign Relations of the United States, vol. vi, pp. 102-5, 1967.

[20] Generalissimo Chiang's meeting with Wallace at 9 o'clock on June 23, 1944 [Z], Communications Between Generalissimo Chiang and President Roosevelt, (Taiwan) China Research Center, p. 233, 1978.

[21] J. Cheng, Memories of the Yan'an Communication Division, China Youth Press, p. 190, 1986.

[22] J .Paton Davies Jr., Dragon by the Tail, the Commercial Press, p.272, 1996.

[23] H. M. Yu, Preparation and Decision-Making of the U.S. Dispatching a Military Observation Group to Yan'an, History Research of the Communist Party of China, vol. 3, p .46, 2006.

[24] P. Viadmilov, The Viadmilov Diaries Yanan China: 1942-1945, Modern Historical Materials Compilation Press, p. 236, 1980.

[25] Vice President Wallace's telegraph to president Roosevelt, Foreign Relations of the United States, vol. vi, pp. 235-7, 1967.

[26] Wallace accepted the influence of pro-Communist figures while visiting China, Foreign Relations of the United States, vol. vi, pp. 364-7, 1967.

[27] C. E. LeMay and B. Yenne, Superfortress: The Story of the B-29 and American Air Force, McGraw-Hill, 1988

[28] G. Thomas and M. Morgan Witts, Enola Gay: The Bombing of Hiroshima, Xinhua Press, p. 278, 1980.

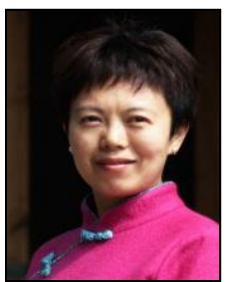

Hu Yueying got the Ph.D. of history in Sichuan University, China.

She is the vice researcher from History \& Culture Research Institute, Chengdu Academy of Social Sciences. She has pubulished the monograph $O n$ the Operation Matterhorn in the late World War II, (Beijing, China, Zhonghua Book Company).

Dr. Hu's On the Operation Matterhorn in the late World War II was supported by The National Social Science Found of China(Grant No:15FZS021) 